\title{
Kualitas Daging Domba dengan Penerapan Teknologi Marinasi Menggunakan Kuwak Fementasi terhadap Masa Simpan
}

\section{(Quality of Mutton Meat with Application of Marinated Technology Using Kluwak Femmentation in the Shelf Life)}

\author{
Patriani $\mathrm{P}^{1}$, Hafid $\mathrm{H}^{2}$, Mirwandhono $\mathrm{E}^{1}$, Wahyuni $\mathrm{TH}^{1}$ \\ ${ }^{1}$ Program Studi Peternakan Fakultas Pertanian Universitas Sumatera Utara, Medan 20155 \\ ${ }^{2}$ Jurusan Peternakan Fakultas Peternakan Universitas Halu Oleo, Kampus Anduonohu Kendari 93232 \\ Penipatriani@usu.ac.id
}

\begin{abstract}
Mutton meat is a protein source for small ruminants. Mutton meat contains high protein and is easily damaged. One preservation method extends the shelf life of meat easily by using herbs such as fermented kluwak seeds (Pangium edule). In addition to extending the shelf life, it is also useful to add flavor to mutton, which some people do not like the aroma. This study aims to determine the best level marination using 40 days of fermentation in different shelf life. Parameters in this study were $\mathrm{pH}$, water content, color and texture, and aroma of mutton meat. The experimental design in this study was factorial with 3 replications. The results showed that the kluwak marination technology in different shelf life had a very significant effect on meat color and $\mathrm{pH}(\mathrm{P}<0.01)$, but did not significantly influence $(\mathrm{P}>0.05)$ on the water content and texture of lamb meat. The use of kluwak fermentation marinade technology with a level of 3\% (P1) to level 9\% (P3) at a shelf life of 12 hours (T1) to 36 hours (T3) provides good quality lamb meat in terms of $\mathrm{pH}$ value, color, water content, and the texture of lamb.
\end{abstract}

Key words: Marination, meat quality, shelf life, kluwak fermentation

\begin{abstract}
ABSTRAK
Daging domba merupakan sumber nutrisi yang baik dari ruminansia kecil. Daging domba mengandung protein sehingga sangat rentan mengalami kerusakan. Salah satu metode preservasi untuk memperpanjang masa simpan daging yang mudah dan murah diantaranya dengan menggunakan rempah yaitu biji kluwak fermentasi (Pangium edule). Selain memperpanjang masa simpan, kluwak sebagai rempah asli Indonesia juga bermanfaat untuk menambah cita rasa pada daging domba yang sebagian orang kurang menyukai aromanya. Penelitian ini bertujuan untuk mengetahui level terbaik marinasi menggunakan kluwak fermentasi 40 hari pada masa simpan yang berbeda terhadap $\mathrm{pH}$, kadar air, warna dan tekstur daging domba. Rancangan yang digunakan adalah faktorial dengan 3 kali ulangan. Hasil penelitian menunjukkan bahwa teknologi marinasi kluwak pada masa simpan yang berbeda berpengharuh sangat nyata terhadap warna daging dan $\mathrm{pH}$ daging $(\mathrm{P}<0,01)$, namun tidak berpengaruh signifikan $(\mathrm{P}>0,05)$ terhadap kadar air dan tekstur daging domba. Penggunaan teknologi marinasi kluwak fermentasi dengan level 3\% (P1) sampai dengan level 9\% (P3) pada masa simpan 12 jam (T1) sampai dengan 36 jam (T3) memberikan kualitas daging domba yang cukup baik ditinjau dari nilai $\mathrm{pH}$, warna, kadar air, dan tekstur daging domba.
\end{abstract}

Kata kunci: Marinasi, kualitas daging, masa simpan, kluwak fermentasi 


\section{PENDAHULUAN}

Daging domba merupakan sumber protein hewani dari ternak ruminansia kecil. Kandungan nutrisi yang cukup tinggi terutama protein, menyebabkan mikroba cepat berkembang sehingga menyebabkan penurunan kualitas daging lebih cepat (Hafid 2017). Selain hal tersebut, daging domba juga salah satu media yang cocok bagi pertumbuhan mikroba sehingga mudah mengalami penurunan kualitas. Suatu metode preservasi untuk mempertahankan kualitas daging sangat diperlukan. Salah satu metode untuk mempertahankan kualitas daging pasca panen misalnya dengan metode pembekuan dan menyimpan daging menggunakan balok es batu (Hafid et al. 2017), namun berbagai kendala seperti gangguan atau belum adanya sumber listrik yang digunakan untuk freezer ataupun pendingin sering terjadi khususnya di daerah pedesaan. Metode lain yang praktis untuk preservasi daging segar yang akan dijual adalah dengan menambahkan berbagai macam bahan pengawet kimia yang dilarang penggunaanya yaitu formalin, borak dan natrium nitrat yang berbahaya bagi kesehatan konsumen jika dikonsumsi terus menerus.

Usaha preservasi daging domba dengan bahan yang murah dan tersedia melimpah seperti biji kluwak adalah salah satu alternatif untuk mengatasi berbagai permasalahan tersebut. Kluwak mudah didapat dan murah manfaat lainya adalah kandungan alaminya tidak berbahaya untuk kesehatan tubuh dan mengandung berbagai senyawa yang diduga dapat memperpanjang masa simpan produk pangan hewani. Kluwak dalam bahasa latin adalah Pangium edule yang bijinya di fermentasi dengan cara khusus, di Indonesia kluwak digunakan sebagai rempah-rempah atau bumbu tradisional (Andarwulan et al. 1999).

Serbuk dan ekstrak biji kluwak mengandung senyawa minyak atsiri, sterol, asam lemak, flavonoid, tanin dan saponin (Aminah 2008). Kandungan senyawa anti bakteri seperti antioksidan sebagai antikanker antara lain vitamin C, beta karotenin dan senyawa golongan flavanoid sebagai anti bakteri yakni asam hidrokarpat, asam khaulmograt, tanin dan asam glorat, (Manuhutu 2011). Kluwak mengadung senyawa antioksidan dan senyawa antibakteri (Ramadhani 2013). Kluwak juga mengandung tanin (Ismaini 2007). Tanin adalah suatu senyawa yang bersifat toksik pada jamur, khamir dan bakteri (Kusmawarti \& Indriyati 2008). Kluwak dapat dijadikan sebagai pestisida untuk membasmi hama (Sakul et al. 2012). Kluwak segar mengandung sianida dan aktivitas antioksidan sebagai senyawa penangkap radikal bebas dalam tubuh (Maharani et al. 2017). Beberapa penelitian melaporkan biji kluwak dapat digunakan untuk pengawetan pada ikan karena peranan dari senyawa sianida yang terkandung di dalamnya, namun belum diteliti lebih lanjut pada produk peternakan khususnya daging. Tujuan penelitian ini adalah mengetahui pengaruh marinasi pada level kluwak yang berbeda terhadap masa simpan dan interaksi keduanya terhadap kualitas daging domba. Manfaat penelitian ini ialah tersedianya informasi tentang cara mempertahankan kualitas daging domba, pengembangan teknologi bagi masyarakat dalam bidang pengawetan pangan asal ternak menggunakan bahan alami yaitu kluwak fermentasi dan memanfaatkan bahan pengawet alami tradisonal yang melimpah di Indonesia.

\section{MATERI DAN METODE}

Materi yang digunakan adalah daging domba jantan umur lebih dari 1 tahun dengan pengambilan daging pada bagian paha dan kluwak yang difermentasi selama 40 hari. Penelitian ini menggunakan rancangan acak lengkap faktorial dengan perlakuan variasi level kluwak (P) dan lama penyimpanan (T) dengan 3 kali ulangan. Apabila hasil analisis 
ragam berpengaruh nyata maka akan dilakukan analisa lanjut dengan uji berjarak Duncan. Parameter dalam penelitian ini adalah pengukuran $\mathrm{pH}$, warna, kadar air, tekstur dan aroma daging domba. Daging domba tersebut direndam dalam marinasi kluwak fermentasi (P) dengan level berbeda yaitu (P0) 0\%, (P1) 3\%, (P2) 6\% dan (P3) 9\% dan daging tersebut disimpan (T) selama (T1) 12 jam, (T2) 24 jam dan (T3) 36 jam dalam suhu ruang. Bahan yang digunakan adalah kluwak yang telah difermentasi selama 40 hari (Elite et al. 2017), diangin-anginkan dan dipanaskan selama selama 1-2 hari , kemudian dikeringkan dengan menggunakan oven dan diblender sampai halus (Fridaqua 2015).

\section{Pengukuran pH daging}

Parameter yang diukur pada penelitian ini adalah $\mathrm{pH}$ daging menggunakan alat $\mathrm{pH}$ meter (Merthayasa et al. 2015). Daging ditimbang 5 gram kemudian dimarinasi 1 jam dalam kluwak fermentasi yang diblender selama 1 menit dan ditambahkan aquadest 10 $\mathrm{ml}$.

\section{Pengukuran warna}

Pengukuran warna digunakan untuk mengukur warna daging segar dan daging yang tidak segar dapat menggun akan metode L*, a* dan b* (Bintoro et al. 2006). Pengukuran warna menggunakan kromameter dengan menggunakan sistem notasi Hunter yang menggunakan 3 dimensi yaitu $\mathrm{L}^{*}$ yang menyatakan tingkat kecerahan, dengan nilai 0 (hitam dan gelap) sampai 100 (terang dan putih). a* adalah warna kromatik campuran merah dan hijau dengan nilai a+ dari 0 sampai 100, warna merah memiliki nilai -a* dari 0 sampai -80 untuk warna hijau adalah $b^{*}$ yaitu warna kromatik campuran biru dan kuning dengan nilai +b* dari 0 sampai +70 untuk warna biru dan $-b^{*}$ dari nilai 0 sampai -70 untuk warna kuning. Kromameter dikalibrasi dengan warna standar yang sifatnya mendekati warna daging yang diukur. Warna standar yang digunakan adalah warna putih dengan nilai +100 dengan panjang gelombang 400 - 700 nm (Bintoro et al. 2006).

\section{Pengukuran tekstur daging}

Kualitas sensoris yang diukur dalam penelitian ini adalah keempukan yang mengacu pada Hafid \& Syam (2007), Prayitno et al (2010) dan Hafid et al. (2018). Untuk tekstur dan aroma/rasa mengacu pada 5 penilaian yakni:

Tabel 1. Uji organoleptik tekstur dan aroma/rasa

\begin{tabular}{lcc}
\hline \hline Skor & Tekstur & Aroma/rasa \\
\hline 5 & Sangat halus (extreme smooth) & Sangat gurih \\
4 & Halus (smooth) & Gurih \\
3 & Agak halus (rather smooth) & Agak gurih \\
2 & Kasar (rough) & Tidak gurih \\
1 & Sangat kasar (extreme rough) & Sangat tidak gurih \\
\hline
\end{tabular}

Sumber: Hafid \& Syam (2007); Prayitno et al. (2010); Hafid et al. (2018)

Uji sensoris daging dilakukan dengan perebusan daging, menggunakan metode skoring oleh 15 orang panelis. 


\section{Pengukuran kadar air}

Analisa kadar air menggunakan metode (AOAC 1984) yakni sampel daging sebanyak 5 gram dimasukkan dalam cawan kemudian dioven selama 4 jam bersuhu $105^{\circ} \mathrm{C}$ sehingga beratnya konstan. Kemudian didinginkan dan ditimbang dengan rumus:

$\%$ Kadar air $=\frac{\mathrm{a}-\mathrm{b}}{\mathrm{c}} \times 100 \%$

$\mathrm{a}=$ berat cawan + sampel awal (gram)

$\mathrm{b}=$ berat cawan + sampel akhir (gram)

c = berat sampel awal (gram)

Penelitian ini dilaksanakan pada bulan April sampai dengan Mei 2019 di Laboratorium Ilmu Pangan, Universitas Sumatera Utara.

\section{HASIL DAN PEMBAHASAN}

Pengukuran sampel menggunakan metode marinasi pada potongan daging yang sudah empuk biasanya ditujukan untuk menambah flavour dan aroma dengan jangka waktu marinating singkat dan untuk daging yang agak alot waktu marinating biasanya lebih panjang. Marinasi sendiri merupakan cairan berbumbu yang berfungsi sebagai bahan perendam daging yang biasa digunakan untuk meningkatkan rendemen daging, memperbaiki flavor, meningkatkan keempukan, meningkatkan juiciness, daya ikat air, menurunkan susut masak, serta memperpanjang masa simpan (Nurohim et al. 2013). Hasil marinasi dari penelitian ini adalah sebagai berikut:

\section{pH daging domba}

Hasil dari pengukuran sampel daging domba yang di marinasi dengan kluwak dengan rentang waktu yang berbeda dapat dilihat pada Tabel 2.

Tabel 2. pH daging domba pada level kluwak dan masa simpan yang berbeda

\begin{tabular}{lcccc}
\hline \multirow{2}{*}{ Waktu } & \multicolumn{4}{c}{ Level kluwak } \\
\cline { 2 - 5 } & P0 $(0 \%)$ & P1 (3\%) & P2 (6\%) & P3 (9\%) \\
\hline T1 (12 Jam) & $5,82 \pm 0,16^{\mathrm{a}}$ & $5,56 \pm 0,17^{\mathrm{c}}$ & $5,54 \pm 0,35^{\mathrm{c}}$ & $5,57 \pm 0,02^{\mathrm{c}}$ \\
T2 (24 Jam) & $5,41 \pm 0,29^{\mathrm{c}}$ & $5,52 \pm 0,23^{\mathrm{c}}$ & $5,69 \pm 0,25^{\mathrm{b}}$ & $5,67 \pm 0,21^{\mathrm{b}}$ \\
T3 (36 Jam) & $5,33 \pm 0,09^{\mathrm{d}}$ & $5,76 \pm 0,31^{\mathrm{b}}$ & $5,73 \pm 0,10^{\mathrm{b}}$ & $5,63 \pm 0,09^{\mathrm{c}}$ \\
\hline
\end{tabular}

Keterangan: Nilai yang diikuti dengan huruf yang berbeda menunjukkan perbedaan yang sangat nyata $(\mathrm{P}<0,01)$

Berdasarkan tabel 2 dapat dilihat bahwa rataan $\mathrm{pH}$ pada daging domba tanpa marinasi kluwak atau kontrol dengan masa simpan 12 jam (T1) 5,82 lebih tinggi dari masa simpan 24 jam (T2) dan 36 jam (T3). Hasil analisis ragam menunjukan bahwa ada pengaruh perlakuan yang sangat nyata $(\mathrm{P}<0,01)$ marinasi daging domba dengan level kluwak yang berbeda terhadap masa simpan. Hal ini bererti level marinasi kluwak dan masa penyimpanan mempengaruhi nilai $\mathrm{pH}$. $\mathrm{pH}$ dalam penelitian untuk level 3\% (P1), 6\% (P2) dan 9\% (P3) dengan masa simpan 12 jam memiliki nilai lebih rendah dari penelitian yang dilakukan oleh Sunarlim \& Setianti (2000) pH setelah dilayukan 12 jam yaitu 5,58. pH daging tanpa perlakuan (P0) setelah 24 jam (T2) menurun menjadi 5,41 
lebih rendah dari penelitian Sunarlim \& Setianti (2000) pH sehari daging domba 5,59 kemudian mengalami peningkatan pada level 3\% (P1), 6\% (P2) dan 9\% (P3) masingmasing 5,52; 5,69 dan 5,67 lebih rendah dari Hafid et al. (2017) sekitar 6.50. Sedangkan . Nilai $\mathrm{pH}$ terendah didapat pada daging domba tanpa marinasi (P0) pada masa simpan 36 jam (T3) yaitu 5,33. Nilai pH pada 36 jam (T3) untuk level 3\% (P1) sebesar 5,76 kemudian meningkat pada 6\% (P2) yakni 5,73 dan menurun pada level 9\% (P3) yaitu 5,63.

Penurunan $\mathrm{pH}$ pada otot ternak yang sehat dan ditangani dengan baik berjalan secara bertahap yaitu mulai dari 7,0 dan akan mencapai $\mathrm{pH}$ ultimate value akhir sekitar 5,4 -5,8 (Soeparno 2015). Glikogen dalam daging mengalami glikolisis secara an aerob sehingga dihasilkan asam laktat secara bertahap sehingga $\mathrm{pH}$ semakin menurun setelah cadangan glikogen habis tidak tersisa lagi glikogen yang dipecah menjadi asam laktat sehingga menyebabkan $\mathrm{pH}$ daging akan naik secara bertahap karena terjadi proses autolisis protein oleh mikroba (Setiawan et al. 2017). Nilai pH dalam penelitian dengan marinasi kluwak masih dalam rentang yang normal sampai waktu 36 jam pada level 9\% hal ini berarti level kluwak 9\% pada masa simpan 36 jam dapat mempertahankan kualitas daging domba. Sedangkan daging domba tanpa perlakuan (P0) pada waktu 36 jam mengalami penurunan $\mathrm{pH}$ sampai 5,33 dapat dikategorikan daging PSE (pale soft and exudative) sehingga kurang layak dikonsumsi.

\section{Kadar air daging domba}

Kadar air daging domba dalam penelitian yang dilakukan marinasi menggunakan kluwak selama masa simpan berbeda dapat dilihat pada tabel 3. Berdasarkan analisis ragam, bahwa antara level kluwak 0-9\% selama masa simpansampai 12-36 jam terhadap kadar air daging domba menunjukan hasil yang tidak berbeda nyata $(\mathrm{P}>0,05)$. Rataan kadar air dalam penelitian ini lebih tinggi dari penelitian yang dilakukan oleh Rosyidi (2009) kadar air pada daging domba betina docking dan non-docking dengan pemberian konsentrat 1\% dan 3\% memiliki kadar air 72,46\%-73,40\%.

Tabel 3. Kadar air daging domba menggunakan level kluwak dengan masa simpan

\begin{tabular}{lcccc}
\hline \hline \multirow{2}{*}{ Waktu } & \multicolumn{4}{c}{ Perlakuan } \\
\cline { 2 - 5 } & P0 (0\%) & P1 (3\%) & P2 (6\%) & P3 (9\%) \\
\hline T1 (12 jam) & $76,6 \pm 1,18$ & $76,4 \pm 3,21$ & $75,8 \pm 2,53$ & $75,3 \pm 2,47$ \\
T2 (24 jam) & $75,3 \pm 2,03$ & $75,8 \pm 2,67$ & $75,5 \pm 1,68$ & $75,5 \pm 2,30$ \\
T3 (36 jam) & $75,8 \pm 2,24$ & $76,5 \pm 1,04$ & $76,3 \pm 2,67$ & $75,8 \pm 1,32$ \\
\hline
\end{tabular}

Nilai kadar air yang tinggi dalam penelitian ini kemungkinan disebabkan oleh kandungan kadar air daging domba yang digunakan sebagai sampel dan pengaruh dari metode marinasi atau perendaman dengan bahan dasar kluwak dan aquadest. Sejalan dengan penelitian yang dilakukan oleh Afrianti et al. (2013) tentang perendaman daging ayam menggunakan esktrak daun senduduk bahwa kandungan kadar air yang tinggi dapat diakibatkan oleh kadar air dalam daging yang memang sudah tinggi dan juga air dalam esktak daun senduduk yang digunakan untuk merendam daging. Kadar air dalam penelitian masih dalam persentase yang cukup baik karena menurut Soeparno (2009) bahwa kadar air daging antara 65-80\%. 


\section{Warna daging domba}

Warna daging kambing dalam penelitian diukur menggunakan kromameter. Hasil penelitian dapat dilihat pada Tabel 4 .

Tabel 4. Warna daging domba menggunakan level kluwak dengan masa simpan

\begin{tabular}{lccccc}
\hline \hline \multirow{2}{*}{ Waktu } & Warna & \multicolumn{4}{c}{ Level kluwak } \\
\cline { 3 - 6 } & & P0 $(0 \%)$ & P1(3\%) & P2(6\%) & P3 (9\%) \\
\hline T1 (12 jam) & L $^{*}$ & $37,19^{\mathrm{a}}$ & $37,52^{\mathrm{a}}$ & $33,51^{\mathrm{b}}$ & $33,02^{\mathrm{b}}$ \\
& $\mathrm{a}$ & $10,53^{\mathrm{a}}$ & $8,95^{\mathrm{b}}$ & $9,91^{\mathrm{a}}$ & $9,35^{\mathrm{b}}$ \\
& $\mathrm{b}^{*}$ & $0,78^{\mathrm{c}}$ & $5,87^{\mathrm{b}}$ & $4,93^{\mathrm{b}}$ & $6,12^{\mathrm{a}}$ \\
T2 (24 jam) & $\mathrm{L}^{*}$ & $37,78^{\mathrm{a}}$ & $32,04^{\mathrm{b}}$ & $31,51^{\mathrm{b}}$ & $33,05^{\mathrm{b}}$ \\
& $\mathrm{a}$ & $9,12^{\mathrm{b}}$ & $10,34^{\mathrm{a}}$ & $10,11^{\mathrm{a}}$ & $9,45^{\mathrm{b}}$ \\
& $\mathrm{b}^{*}$ & $0,70^{\mathrm{c}}$ & $6,02^{\mathrm{a}}$ & $6,14^{\mathrm{a}}$ & $4,86^{\mathrm{b}}$ \\
& $\mathrm{L}$ & $31,36^{\mathrm{b}}$ & $34,60^{\mathrm{b}}$ & $33,70^{\mathrm{b}}$ & $32,56^{\mathrm{b}}$ \\
& $\mathrm{a}$ & $8,80^{\mathrm{b}}$ & $8,96^{\mathrm{b}}$ & $9,85^{\mathrm{b}}$ & $8,98^{\mathrm{b}}$ \\
& $\mathrm{b}^{*}$ & $0,51^{\mathrm{c}}$ & $6,60^{\mathrm{a}}$ & $5,76^{\mathrm{b}}$ & $5,53^{\mathrm{b}}$ \\
\hline
\end{tabular}

Keterangan: Nilai yang diikuti dengan huruf yang berbeda menunjukkan perbedaan yang sangat nyata $(\mathrm{P}<0,01)$

Pengujian untuk menentukan ketahanan daging domba apakah daging tersebut sudah busuk atau masih segar dapat menggunakan uji warna dengan alat kromameter. Daging segar biasanya memiliki warna yang berbeda dari daging yang sudah busuk. Karakteristik warna metode $\mathrm{L}^{*}$, a* dan $\mathrm{b}^{*}$ dapat membedakan secara signifikan otot yang berwarna gelap dan terang (Boulianne \& King 2007). Metode $L^{*}, a^{*}$ dan $b^{*}$ dengan alat kromameter menghasilkan data rerata warna daging domba pada Tabel 4.

Berdasarkan data tabel 4 rataan kecerahan ( $\mathrm{L}^{*}$ ) daging domba pada masa simpan 12 jam (T1) tanpa perlakuan, masa simpan 12 jam (T1) dengan level 3\% (P1) dan 36 jam (T2) tanpa perlakuan memiliki kecerahan lebih tinggi jika dibandingkan dengan sampel daging perlakuan lainya. Hasil analisis ragam menunjukan perlakuan level marinasi menggunakan kluwak fermentasi memberikan pengaruh yang nyata terhadap warna daging dan lama penyimpanan. Hasil uji lanjut DMRT pada taraf 5\% menunjukan adanya perbedaan antar perlakuan berbeda nyata pada tingkat kecerahan dan warna kemerahan daging terhadap masa simpan. Sedangkan pada taraf $1 \%$ ada perbedaan yang sangat nyata ditunjukan oleh Kandungan warna $\mathrm{b}^{*}$ atau warna kekuningan terhadap masa simpan. Warna daging pada sampel tanpa perlakuan (P0) lebih cerah dibanding perlakuan 3\% (P1), 3\% (P2) dan 9\% (P3). Tingkat kecerahan ( $\mathrm{L}^{*}$ ) daging domba pada perlakuan lebih rendah dibanding dengan kontrol (P0) kemungkinan disebabkan adanya kandungan warna coklat kekuningan yaitu tanin pada kluwak yang meresap pada permukaan daging sehingga dapat mengurangi tingkat kecerahan.

Tingkat kemerahan (a*) daging domba pada T1 dan T2 lebih tinggi dari T3 dan level kluwak dengan tingkat kemerahan tertinggi tanpa perlakuan (P0) pada waktu 12 jam (T1). Berbeda dengan penelitian yang dilakukan oleh (Bintoro et al. 2006) pada daging ayam bahwa semakin tinggi warna merah ( $\left.a^{*}\right)$ menunjukan bahwa daging tersebut adalah daging bangkai sedangkan dalam penelitian ini daging domba dengan waktu (T1) 12 jam 
dan (T2) 24 jam memiliki warna yang lebih merah dari daging (T3) pada 36 jam. Hal ini diduga karena adanya perlakuan yaitu penambahan kluwak sehingga mempengaruhi warna daging yang disebabkan adanya kandungan tannin dalam kluwak. Selain hal tersebut, perbedaan warna daging pada unggas atau daging putih dan daging merah pada ruminansia juga diduga berpengaruh terhadap kandungan warna merah.

Kandungan warna $b^{*}$ atau warna kekuningan berbeda sangat nyata antar perlakuan. Daging domba tanpa perlakuan pada 12 jam (T1), 24 jam (T2) dan 36 jam (T3) memiliki intensitas warna kekuningan lebih rendah dari perlakuan 3\% (P1), P2 (6\%) dan P3 (9\%) dengan waktu 12, 24 dan 36 jam. Menurut Bintoro et al. (2006) tingkat kekuningan daging ayam segar lebih tinggi daripada daging ayam bangkai. Intensitas warna pada level perlakuan yang cukup tinggi diduga karna pengaruh zat warna yang terkandung dalam kluwak yakni tanin yang berwarna coklat muda kekuningan sangat mempengaruhi warna daging yang mendapatkan perlakuan level kluwak P1,P2 maupun P3.

\section{Tekstur daging domba}

Hasil penelitian menunjukan bahwa skor pada tekstur daging domba pada level kluwak dan masa simpan tidak berbeda nyata $(\mathrm{P}>0,05)$. Hal ini berarti bahwa penambahan kluwak sampai level 9\% dan waktu 36 jam tidak berpengaruh terhadap keempukan daging domba secara organoleptik. Skor tekstur daging domba dalam penelitian antara 3,67 sampai 3,93 antara tekstur agak halus sampai halus.

Tabel 5. Tekstur daging domba

\begin{tabular}{lcccc}
\hline \multirow{2}{*}{ Waktu } & \multicolumn{4}{c}{ Level kluwak } \\
\cline { 2 - 5 } & P0 (0\%) & P1 (3\%) & P2 (6\%) & P3 (9\%) \\
\hline T1 (12 jam) & 3,67 & 3,80 & 3,67 & 3,73 \\
T2 (24 jam) & 3,67 & 3,87 & 3,93 & 3,80 \\
T3 (36 jam) & 3,73 & 3,67 & 3,73 & 3,87 \\
\hline
\end{tabular}

Tekstur pada daging domba relatif dalam kisaran yang sama, hal ini dapat disebabkan level kluwak dan masa simpan tidak berpengaruh pada serabut-serabut otot daging domba. Beberapa faktor dapat berpengaruh terhadap tingkat kekasaran suatu bahan salah satu contoh adalah dengan bertambahnya umur ternak maka dapat meningkatkan tingkat kekasaran pada daging. Ternak yang dipelihara lepas mempunyai aktivitas fisik yang lebih besar dan akan mempunyai ukuran jaringan ikat yang lebih besar sehingga menyebabkan tekstur daging lebih kasar (Hafid et al. 2018). Menurut Soeparno (2005) otot dengan serabut yang kecil tidak menunjukan peningkatan kekasaran tekstur. Tekstur dalam penelitian ini termasuk dalam kategori penilaian agak halus sampai halus hal ini berarti level kluwak dan masa simpan yang berbeda menghasilkan daging dengan kualitas yang cukup baik.

\section{KESIMPULAN}

Dari hasil penelitian dapat disimpulkan bahwa penggunaan teknologi marinasi menggunakan kluwak dengan level fermentasi 3\% (P1) sampai 9\% (P3) dengan masa simpan 12 jam (T1) sampai dengan 36 jam (T3) memberikan kualitas daging domba yang cukup baik ditinjau dari nilai $\mathrm{pH}$, warna, kadar air, dan tekstur daging domba. Ditinjau 
dari kualitas fisik penggunaan level kluwak 3\% (P1) pada masa simpan (T1) 12 jam sampai dengan (T3) 36 jam memberi hasil terbaik dalam penelitian ini.

\section{UCAPAN TERIMA KASIH}

Kami mengucapkan terimakasih sebesar-besarnya kepada Universitas Sumatera Utara dan Lembaga Penelitian Universitas Sumatera Utara dalam program pendanaan penelitian Talenta 2019 yang telah memberikan bantuan kepada kami dalam penelitian ini. Terimakasih juga kami sampaikan pada Laboratorium Ilmu Pangan Fakultas Pertanian Universitas Sumatera Utara yang telah berkontribusi sehingga penelitian kami berjalan lancar. Kami juga berterimakasih pada pihak yang berkontribusi dan terkait dalam penelitian ini.

\section{DAFTAR PUSTAKA}

Aminah. 2008. Potensi Pangium edule Reinw (picung) sebagai agen pengendali hayati, Tahap II [Internet]. [diakses 3 April 2018]. Tersedia dari: http://www.ekologi.litbang.depkes.go.id/data/abstrak.

Afrianti M, Dwiloka B, Setiani BE. 2013. Total bakteri pH, dan kadar air daging ayam broiler setelah direndam dalam ekstrak daun senduduk (Melastoma malabathricum L.) selama masa simpan. J Pangan Gizi. 4.

Andarwulan N, Fardiaz F, Apriyanto A, Purwarianto, Hariyadi, Shetty K.1999. Mobilization of primary metabolites and phenolics during natural fermentation in seeds og Pangium edule Reinw. J Process Biochem. 35:197-204.

AOAC. 1984. Official method of analysis. Washington DC (USA): Association of Official Analytical Chemists.

Bintoro VP, Dwiloka D, Sofyan A. 2006. Perbandingan daging ayam segar dan daging bangkai dengan memakai uji fisiko kimia dan mikrobiologi Test. J Indones Trop Anim Agric. 31.

Boulianne M, King AJ. 1998. Meat colorand biochemical characteristics of unacceptable dark-colored broiler chickencarcasses. J Food Sci. 63:543-549.

Fridaqua YS. Ekstraksi tannin dari kluwak (Pangium edule R) menggunakan pelarut etanol dan aquades dan aplikasinya sebagai pewarna makanan [Tesis]. [Malang (Indonesia)]: Universitas Negeri Malang.

Elite GS, Sukinah A, Amirah M. 2017. Analisis kualitas kluwak (Pangium edule reinw) fermentasi menggunakan media tanah dan abu sekam. J Pendidikan Teknologi Pertanian. 3:25-33.

Hafid H, Syam A. 2007. Pengaruh aging dan lokasi otot terhadap kualitas organoleptik daging sapi Buletin Peternakan. 31:209-216.

Hafid H. 2017. Pengantar pengolahan daging: Teori dan praktik. Cetakan Pertama. Bandung (Indonesia): Penerbit Alfabeta.

Hafid H, Napirah A, Meliana L. 2017. Efek pencairan kembali terhadap pH, susut masak, dan warna daging sapi bali yang dibekukan. Prosiding Seminar Nasional Teknologi Peternakan dan Veteriner. Bogor (Indonesia): Pusat Penelitian dan Pengembangan Peternakan. p. 275-279. 
Hafid H, Napirah A, Sarifu SM, Rahman, Inderawati, Nuraini, Hasnudi. 2018. Effect of Electrical stimulation on physical and organoleptic properties of muscovy duck meat. JITV. 23:202-209.

Hafid H, Nuraini, Inderawati, Kurniawan W. 2018. Beef cattle characteristic of differant butt shape condition. IOP Conference Series Earth and Environmental Science. p. 1-6.

Ismaini L. 2007. Studi aktivitas dan analisis kimia senyawa antibakteri dari ekstrak biji picung [Tesis]. [Depok (Indonesia)]: Universitas Indonesia.

Kusmawarti A, Indriati N. 2008. Daya hambat ekstrak bahan aktif biji picung (Pangium edule). J Pascapanen Bioteknologi Kelautan Perikanan. 3.

Manuhutu E. 2011. Efektivitas biji kluwak (Pangium edule reinw) sebagai bahan pengawet alami terhadap beberapa sifat mutu dan masa simpan ikan cakalang (Yellowfin Tuna) [Tesis]. [Manado (Indonesia)]: Universitas Sam Ratulangi Manado.

Maharani NPMT, Muljati TPS, Nurcholis. 2017. Kandungan asam sianida dan aktivitas antioksidan pada kluwak (Pangium edule Reinw) setelah proses perebusan. J Analisis Kesehatan Sains. 6.

Merthayasa JD, Ketut IS, Kadek KA. 2015. Daya ikat air, pH, warna, bau dan tekstur daging sapi bali dan daging wagyu, Indonesia. Medicus Veterinus. 4:16-24.

Nurohim, Nurwantoro, Sunarti D. 2013. Pengaruh metode marinasi dengan bawang putih pada daging itik terhadap $\mathrm{pH}$, daya ikat air dan total coliforma. Anim Agric J. 2:78.

Prayitno AH, Suryanto E, Zuprizal. 2010. Physical and sensoryquality of meat of broiler chicken fed witd the addition of virgin coconut oil. Buletin Peternakan. 34:55-63.

Ramadhani E, Chainul F, Rahmiwati H. 2013. optimalisasi penggunaan biji kluwak (Pangium edule Reinw) terhadap mutu ikan patin jambal siam (Pangasius sucthi) segar selama peyimpanan pada suhu kamar. Photon J Sains Kesehatan. 3.

Rosyidi J. 2009. Kualitas daging domba ekor gemuk betina periode lepas sapih dengan perlakuan docking dan tingkat pemberian konsentrat ditinjau dari kadar air, lemak. J Ilmu Teknologi Hasil Ternak. 4:30-35.

Sakul E, Manoppo J, Taroreh D, Gerungan R. 2012. Pengendalian hama kumbanglogong (Sitophylus oryzae, L) dengan ekstrak biji keluek (Pangium edule Reinw). J Eugenia. 18:24-35.

Soeparno. 2009. Ilmu dan teknologi daging. Yogyakarta (Indonesia): UGM Press.

Sunarlim R, Setianto H. 2000. Pelayuan pada suhu kamar dan suhu dingin terhadap mutu daging dan susut bobot karkas domba. JITV. 6 . 